\title{
The Contribution of Perch (Perca fluviatilis L. 1758) to Maintaining the Diphyllobothriasis Focus in the Krasnoyarsk Reservoir and the Yenisei River
}

\author{
Julia K. Chugunova*a, \\ Tatyana Yu. Ronzhina ${ }^{\mathrm{b}}$ and Alexey A. Syromyatnikov \\ ${ }^{a}$ Research Institute for Ecology of Fishery Waterbodies \\ Krasnoyarsk, Russian Federation \\ ${ }^{b}$ V.M. Krutovsky Krasnoyarsk Specialized Medical College \\ Krasnoyarsk, Russian Federation \\ ${ }^{c}$ V.P. Astafyev Krasnoyarsk State Pedagogical University \\ Krasnoyarsk, Russian Federation
}

\begin{abstract}
The study investigates infection rates of perch by plerocercoids of the Dibothriocephalus latus (Linnaeus, 1758) Lühe, 1899 (syn. Diphyllobothrium latum) broad tapeworm in the creeks of the Krasnoyarsk Water Reservoir and in the Yenisei River (within the limits of the city of Krasnoyarsk). Plerocercoids were found in the perch in all study areas. The rates of invasion of the fish in the Yenisei River and in the creeks of the lower part of the Reservoir - Biryusa and Shumikha - were low (9.8, 6.9 , and $13.5 \%$, respectively); the infection of perch was higher in the middle part of the Reservoir, in the Sisim Creek (21.4\%). The fish purchased at an unauthorized market was the most infected $-68.5 \%$. The sample included large fish, weighing from 70 to $970 \mathrm{~g}$. A positive correlation was noted between invasion rate and fish age $(\mathrm{r}=0.7)$. The plerocercoids found in the fish were viable. They were mainly localized in the fish muscle. Diphyllobothriosis is a commonly occurring helminthiasis in the riverine communities transformed because of the damming of rivers. In the Krasnoyarsk Water Reservoir, the broad tapeworms are usually transmitted along the plankton - perch - pike chain. The data obtained in this study show that small perch, consuming infected plankton, plays a leading role in maintaining the abundance of D. latus in the water reservoir. However, the main contribution to the epidemiological situation in the region is made by the large perch, which is heavily infected with broad tapeworm plerocercoids because of its cannibalistic feeding behavior. Both recreational fishermen and the people purchasing fish at unauthorized markets prefer large perch. Commercial and recreational fishing,
\end{abstract}

(C) Siberian Federal University. All rights reserved

This work is licensed under a Creative Commons Attribution-NonCommercial 4.0 International License (CC BY-NC 4.0).

* Corresponding author E-mail address: jhermann@mail.ru

ORCID: 0000-0001-6925-5851 (Chugunova J.) 
settlements on the shores of the Reservoir, and the increasing number of tourists have contributed to the invasion of pathogenic organisms in the Reservoir. The perch caught in the Krasnoyarsk Water Reservoir or in the Yenisei River or purchased at unauthorized markets, which have not been inspected for disease, could be a source of diphyllobothriosis infection for people.

Keywords: perch, plerocercoids, Dibothriocephalus latus, diphyllobothriosis, infection rate.

Citation: Chugunova J.K., Ronzhina T.Yu., Syromyatnikov A.A. The contribution of perch (Perca fluviatilis L. 1758) to maintaining the diphyllobothriasis focus in the Krasnoyarsk Reservoir and the Yenisei River. J. Sib. Fed. Univ. Biol., 2020, 13(3), 297-309. DOI: 10.17516/1997-1389-0329

\title{
Роль окуня (Perca fluviatilis L. 1758) \\ в поддержании очага дифиллоботриоза \\ в Красноярском водохранилище и р. Енисей
}

\author{
Ю.К. Чугунова \\ Т.Ю. Ронжина ${ }^{\sigma}$, А.А. Сыромятников ${ }^{\mathrm{B}}$ \\ ${ }^{a}$ Научно-исследовательский институт экологии \\ рыбохозяйственных водоемов \\ Российская Федераиия, Красноярск \\ ${ }^{6}$ Красноярский базовый медииинский колледж \\ им. В.М. Крутовского \\ Российская Федераиия, Красноярск \\ ${ }^{6}$ Красноярский государственный педагогический университет \\ им. В.П. Астафьева \\ Российская Федерачия, Красноярск
}

Аннотация. Исследована зараженность окуня плероцеркоидами широкого лентеца Dibothriocephalus latus (Linnaeus, 1758) Lühe, 1899 (syn. Diphyllobothrium latum) в заливах Красноярского водохранилища и в р. Енисей (в черте г. Красноярска). Плероцеркоиды были обнаружены у окуня на всех исследованных участках. Низкий процент инвазии отмечен у рыб в р. Енисей $-9,8$ \% и в заливах нижней части водохранилища: Бирюса $(6,9 \%)$ и Шумиха $(13,5$ \%), зараженность окуня выше в средней части: залив Сисим (21,4 \%). Рыба, приобретенная на несанкционированном рынке г. Красноярска, оказалась наиболее зараженной - 68,5 \% (в выборке присутствовали крупные особи, массой от 70 до 970 г). Отмечена положительная корреляция интенсивности инвазии с возрастом рыб. Обнаруженные плероцеркоиды были жизнеспособны. Основная локализация плероцеркоидов - мускулатура рыб. Дифиллоботриоз является распространенным гельминтозом в условиях трансформации речных сообществ при зарегулировании стока. В Красноярском водохранилище основной путь циркуляции широкого лентеца проходит в цепи: планктон - окунь - щука. Полученные данные показали, что мелкий окунь, потребляя зараженный планктон, играет ведущую роль в поддержании численности 
D. latus в водохранилище. Однако эпидемиологическая обстановка в регионе связана с крупным окунем, высокая зараженность которого плероцеркоидами широкого лентеца объясняется типом его питания (каннибализм). Крупный окунь - предпочитаемый пищевой продукт как для рыбаков-любителей, так и для населения, приобретающего рыбу на несанкционированных рынках. Промышленное и любительское рыболовство, населенные пункты на берегах водохранилища, а также увеличивающийся туристический поток способствуют поступлению в водоем инвазионного начала. Окунь, выловленный в Красноярском водохранилище или p. Енисей, а также приобретенный в местах несанкционированной торговли и не прошедший ветеринарно-санитарную экспертизу, может быть источником заражения человека дифиллоботриозом.

Ключевые слова: окунь, плероцеркоид, Dibothriocephalus latus, дифиллоботриоз, зараженность.

Цитирование: Чугунова, Ю.К. Роль окуня (Perca fluviatilis L. 1758) в поддержании очага дифиллоботриоза в Красноярском водохранилище и р. Енисей / Ю.К. Чугунова, Т.Ю. Ронжина, А.А. Сыромятников // Журн. Сиб. федер. ун-та. Биология, 2020. 13(3). С. 297-309. DOI: 10.17516/1997-1389-0329

\section{Введение}

Дифиллоботриоз на территории Красноярского края по-прежнему остается важной медико-социальной проблемой и, несмотря на некоторую тенденцию к снижению заболеваемости населения, занимает третье место в статистике гельминтозов, его доля составляет 11,1 \% (показатель заболеваемости в 2017 г. 33,3 на 100 тысяч населения).

Проблеме дифиллоботриоза посвящено много работ в отечественной и зарубежной литературе, особое внимание в последнее время уделяется популяционно-генетическим исследованиям (Bazsalovicsová at al., 2018). К сожалению, в Красноярском крае систематического изучения зараженности рыб плероцеркоидами дифиллоботриид и возможных путей инвазии человека не проводится.

У рыб в этом регионе встречаются три вида личинок дифиллоботриид (Герман, Вышегородцев, 2004), два из которых - лентец широкий Dibothriocephalus latus (Linnaeus, 1758) Lühe, 1899 (syn. Diphyllobothrium latum) и лентец чаечный Dibothriocephalus dendriticus (Nitzsch, 1824) Lühe, 1899 (syn.
Diphyllobothrium dendriticum) - представляют опасность в эпидемиологическом отношении. Рыбы, вторые промежуточные хозяева обоих видов лентецов, неравномерно распространены в водоемах края, и их роль в питании человека также различна. В центральных и южных районах Красноярского края, где созданы крупнейшие водохранилища: Саяно-Шушенское, Красноярское и Богучанское, основу промысла составляют окунь и щука (вторые промежуточные хозяева лентеца широкого), тогда как в северных районах, в бассейнах Енисея, Хатанги, Пясины, озер п-ова Таймыр, преимущество в промысле сохраняется за сиговыми видами рыб (вторые промежуточные хозяева лентеца чаечного).

В первых работах по дифиллоботриозу в Красноярском крае указано, что в бассейне p. Енисей дифиллоботриоз человека вызывает лентец широкий, окончательными хозяевами также могут быть собака и лисица (Козминская, 1964). На севере Красноярского края (п-ов Таймыр, бассейн р. Хатанги) возбудителями дифиллоботриозов являются широкий и 
чаечный лентецы (Клебановский и др., 1977; Делямуре и др., 1985).

В 2017 г., по материалам Управления Роспотребнадзора по Красноярскому краю, зарегистрировано 955 случаев дифиллоботриоза, из них 61,2 \% случаев заболевания связаны с употреблением рыбы из Красноярского водохранилища, 30,5 \% - выловленной в р. Енисей, его притоках и озерах Таймыра, 4,8 \% - за пределами Красноярского края. Известно, что основной путь заражения человека - употребление рыбы, выловленной самостоятельно, в меньшей степени - приобретенной у частных лиц в местах несанкционированной торговли (О состоянии санитарно-эпидемиологического..., 2018).

В качестве объекта паразитологического исследования был выбран окунь - массовый вид в Красноярском водохранилище и объект любительского и спортивного рыболовства в ряде водных объектов края.

Цель настоящей работы - изучение зараженности окуня плероцеркоидами лентеца широкого в заливах Красноярского водохранилища и на участке р. Енисей, имеющих рыбохозяйственное и рекреационное значение, а также оценка качества и безопасности рыбной продукции, поступающей в продажу в местах несанкционированной торговли.

\section{Материалы и методы}

Материал был собран в ноябре-марте 2016-2017 гг. в р. Енисей (в черте г. Красноярска, р-н пос. Удачный) и на Красноярском водохранилище: зал. Шумиха и Бирюса (нижняя часть) и Сисим (средняя часть водохранилища) (рис. 1). Отлов рыбы в р. Енисей проводили крючковыми орудиями лова (спиннинг),

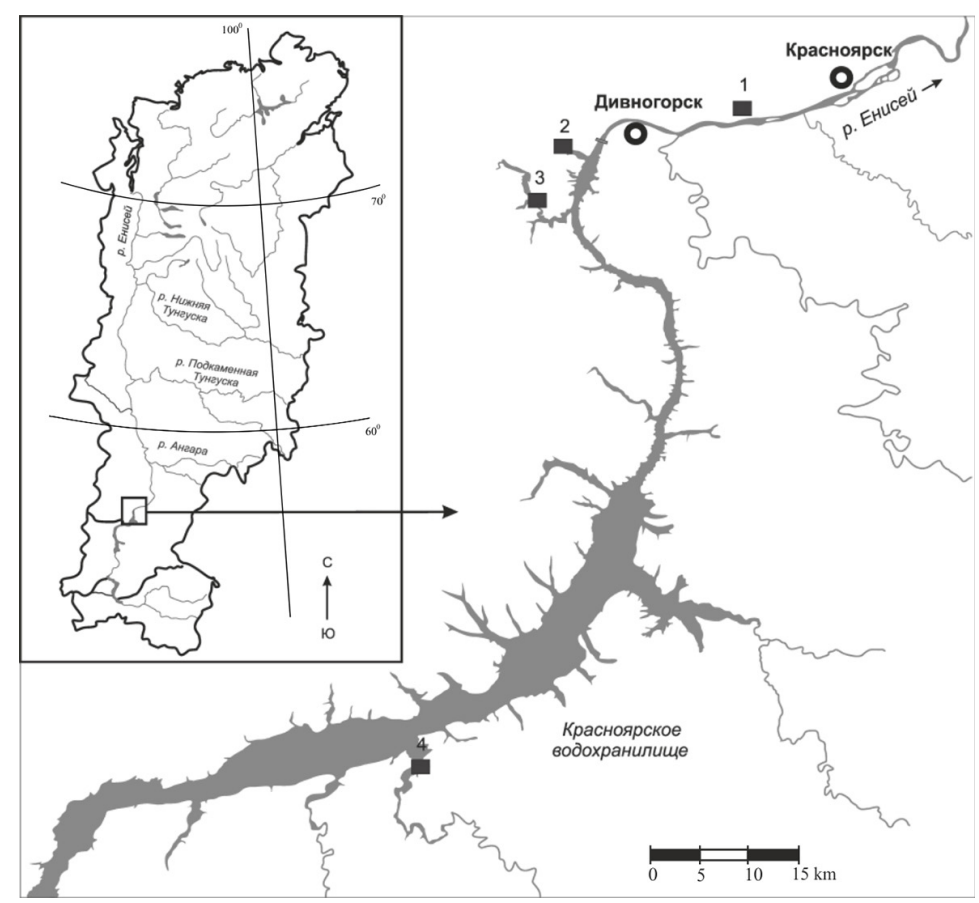

Рис. 1. Карта-схема района исследований: - место отбора проб: 1 - р. Енисей, 2 - зал. Шумиха, 3 - зал. Бирюса, 4 - зал. Сисим

Fig. 1. Diagrammatic map of the study area: - - sampling positions: 1 - Yenisei River, 2 - Shumikha bay, 3 Biryusa bay, 4 - Sisim bay 
в водохранилище - ставными жаберными сетями с размером ячеи 18-35 мм.

Места отбора проб различаются между собой по гидрологическим, гидробиологическим параметрам, а также уровнем антропогенной нагрузки, но все они являются местами любительского рыболовства и отдыха населения Красноярского края.

Дополнительно для определения безопасности рыбной продукции в ветеринарносанитарном отношении на стихийном рынке г. Красноярска у частного лица было приобретено 35 свежезамороженных окуней общим весом 10,2 кг. Место вылова рыбы неизвестно (предположительно из Красноярского водохранилища), ветеринарные документы на продукцию отсутствовали.

Всего методом специального паразитологического вскрытия (просмотрена мускулатура, стенка желудка, жировая ткань и гонады) (Быховская-Павловская, 1985) исследовано 222 экз. окуня (табл. 1). Жизнеспособность плероцеркоидов из замороженной рыбы определяли по морфологическим признакам личинок и наличию у них двигательной активности в соответствии с МУК 3.2.988-00. Для этого личинок помещали в чашку Петри с подогретым до $38{ }^{\circ} \mathrm{C}$ физиологическим раствором и стимулировали движение путем физического раздражения, уколов личинку препаровальной иглой (МУК 3.2.988-00, 2000).

Для количественной характеристики зараженности рыб использовали следующие показатели (Беклемишев, 1961; Пронин и др., 1991):

экстенсивность инвазии $(E, \%)$ :

$$
E=\left(N_{i} \times 100\right) / N,
$$

где $N_{i}$ - количество зараженных рыб, $N$ - количество исследованных рыб;

средняя интенсивность (I) инвазии (количество экз. на одну зараженную рыбу):

$$
I=\sum n / N_{i},
$$

где $\sum n$ - сумма паразитов, обнаруженных в зараженной рыбе;

лимиты интенсивности (минимальнаямаксимальная);

индекс обилия $(M)$ или относительная плотность (количество экз. на одну исследованную рыбу):

$$
M=\sum n / N .
$$

Таблица 1. Количество исследованных рыб и характеристика биологических показателей окуня по участкам, 2016-2017 гг.

Table 1. The number of fish examined and characterization of the biological parameters of perch at different sites, 2016-2017

\begin{tabular}{|l|c|c|c|c|}
\hline \multicolumn{1}{|c|}{$\begin{array}{c}\text { Район } \\
\text { исследований }\end{array}$} & $\begin{array}{c}\text { Число вскрытых } \\
\text { рыб, экз. }\end{array}$ & Возраст, лет & Длина (АВ), мм & Масса, г \\
\hline р. Енисей & 51 & $1+-4+$ & $120-231(153,9 \pm 3,4)$ & $13,5-156(42,5 \pm 3,4)$ \\
\hline Зал. Шумиха & 37 & $2+-5+$ & $123-247(157,9 \pm 4,2)$ & $18-199(46,2 \pm 5,3)$ \\
\hline Зал. Бирюса & 43 & $1+-5+$ & $123-214(173,2 \pm 3,3)$ & $20-135(56,9 \pm 3,6)$ \\
\hline Зал. Сисим & 56 & $2+-6+$ & $160-270(198,9 \pm 3,6)$ & $38-297(96,2 \pm 6,7)$ \\
\hline Неизвестен & 35 & $4+-8+$ & $176-380(255,6 \pm 9,9)$ & $69-970(294,1 \pm 43,1)$ \\
\hline
\end{tabular}

Примечание: длина тела (АВ) абсолютная, от начала рыла до конца хвостового плавника. 
Проверка гипотезы о соответствии полученных данных по численности плероцеркоидов D. latus негативному биномиальному распределению выполнена с использованием программ Quantitative Parasitology 3.0 (Rozsa et al., 2000) и Statgraphics. Оценка однородности выборок распределений (отсутствие/присутствие статистически значимых различий), полученных при изучении различных популяций окуня, проводилась с применением критерия Колмогорова-Смирнова (D) в пакете Statgraphics.

Фотографии выполнены с помощью фотокамеры Canon PowerShot D 10 (фрагмент стробилы гельминта и плероцеркоид в мускулатуре окуня) и цифровой камеры (видеоокуляр) для микроскопа ToupCam 14 МР при увеличении 2х10 микроскопа Микромед МC-2 ZOOM вар. $2 \mathrm{CR}$.

B свете последних исследований систематическое положение широкого лентеца было пересмотрено. Полифилетический род Diphyllobothrium разделен на род Dibothriocephalus с типовым видом Dibothriocephalus latus (Linnaeus, 1758) Lühe, 1899 (ранее известный как Diphyllobothrium latum) и род Diphyllobothrium, виды которого паразитируют у китообразных (Waeschenbach et al., 2017). В настоящей работе используется современное название цестоды - D. latus.

\section{Результаты}

Плероцеркоиды D. latus обнаружены у окуня на всех участках сбора материала, минимальная зараженность у рыб р. Енисей 9,8 \% (табл. 2). В исследуемых заливах Красноярского водохранилища экстенсивность инвазии рыб выше, чем в реке, - 14,7 \%, при этом самая низкая, $6,9 \%$, отмечена у окуня в зал. Бирюса. В средней части водохранилища (зал. Сисим) зараженность рыб существенно выше, чем в низовье, и составляет 21,4 \%. Средняя интенсивность инвазии рыб плероцеркоидами лентеца низкая как в водохранилище, так и в р. Енисей, варьирует от 1,7 до 2,2 экз/зараженную рыбу соответственно. При сходных показателях инвазии (экстенсивность и индекс обилия) распределения численности плероцеркоидов в исследованных выборках окуня из водохранилища и р. Енисей достоверно отличались, тест Колмогорова-Смирнова $\mathrm{DN}=0,90(p<0,05)$.

Окунь, приобретенный на стихийном рынке, оказался самым зараженным - 68,5 \%, индекс обилия - 1,9 экз/исследованную особь хозяина (табл. 2). Все обнаруженные гельминты (за исключением 2 экз.) были живые.

Таблица 2. Зараженность окуня плероцеркоидами Dibothriocephalus latus, 2016-2017 гг.

Table 2. Infestation of perch with Dibothriocephalus latus plerocercoids, 2016-2017

\begin{tabular}{|l|c|c|c|}
\hline \multicolumn{1}{|c|}{ Район исследований } & $E, \%$ & $I$, экз. (lim.) & $M$, экз. \\
\hline р. Енисей & 9,8 & $2,2(1-4)$ & 0,2 \\
\hline $\begin{array}{l}\text { Красноярское водохранилище (в целом по } \\
\text { заливам) }\end{array}$ & 14,7 & $1,7(1-3)$ & 0,2 \\
\hline Зал. Шумиха & 13,5 & $1,2(1-2)$ & 0,2 \\
\hline Зал. Бирюса & 6,9 & $1,3(1-2)$ & 0,09 \\
\hline Зал. Сисим & 21,4 & $1,5(1-3)$ & 0,3 \\
\hline Неизвестен & 68,5 & $2,8(1-7)$ & 1,9 \\
\hline
\end{tabular}

Примечание: $E$ - экстенсивность инвазии, $I$ - интенсивность инвазии, $M$ - индекс обилия. 
У отдельных рыб количество личинок колебалось от 1 до 7, преимущественная локализация - мускулатура (84 \%), единично плероцеркоиды встречались в жировой ткани, икре и стенке желудка. Отмечена положительная корреляция $(\mathrm{r}=0,7)$ средней интенсивности инвазии плероцеркоидами с возрастом рыб.

\section{Обсуждение результатов}

Лентец широкий имеет сложный цикл развития, включающий двух промежуточных и окончательного хозяев. Половой зрелости этот гельминт достигает в тонком отделе кишечника человека (рис. 2) и различных плотоядных (кошки, собаки, медведя, лисицы и др.). В организме человека продолжительность жизни лентеца может достигать 20 лет (Бауер, 1958; Чебышев и др., 2004; Scholz et al., 2009). Взрослые особи широкого лентеца выделяют яйца, из которых при попадании их в воду вылупляются личинки (корацидии). Первым промежуточным хозяином цестоды являются преимущественно массовые представители планктона - веслоногие рачки

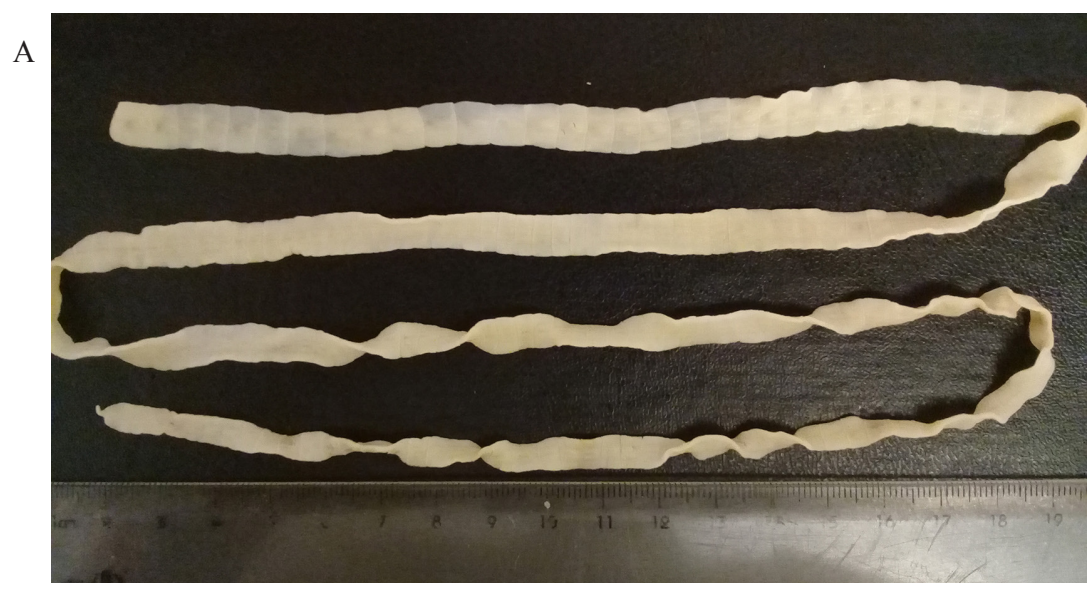

Б

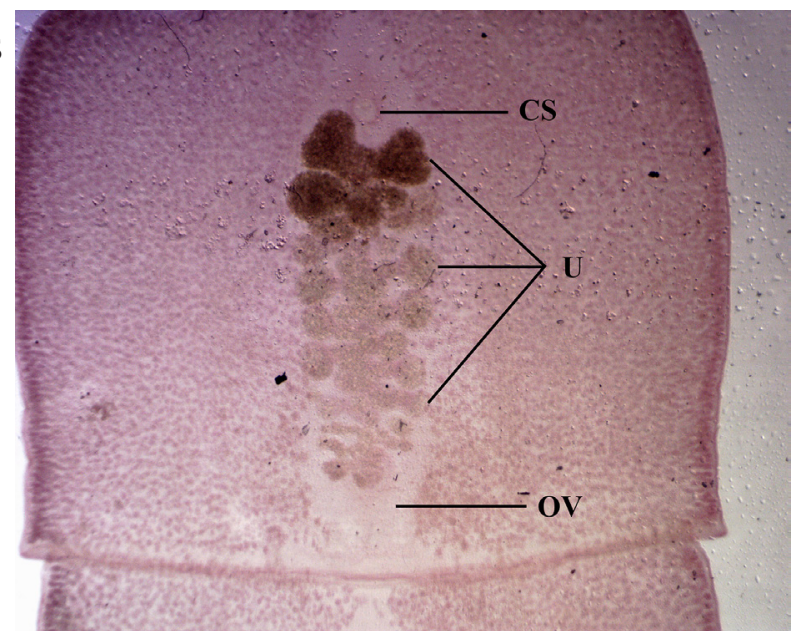

Рис. 2. А - фрагмент стробилы лентеца широкого (D. latus) из человека; Б - гермафродитный членик лентеца широкого (D. latus). CS - Cirrus Sac (сумка цирруса), U - Uterus (матка), OV - Ovary (яичник)

Fig. 2. A - A fragment of a tapeworm strobilus (D. latus) from the human. B - Hermaphroditic segment of a tapeworm (D. latus). CS - Cirrus Sac, U - Uterus, OV - Ovary 
Copepoda, в полости тела которых после проглатывания корацидия развивается личиночная стадия - процеркоид. Следующий этап цикла развития личиночной фазы паразита начинается после поедания зараженных рачков рыбами, у которых формируются инвазионные плероцеркоиды (Гинецинская, 1958; Scholz et al., 2009). Личинки могут находиться в различных органах и тканях рыбы, согласно нашим исследованиям, преимущественно в мускулатуре, единично - в жировой ткани, икре и стенке желудка. Зараженная плероцеркоидами планктоноядная молодь рыб, преимущественно семейства окуневых, обеспечивает длительное существование инвазионного начала в водоеме. При этом для увеличения устойчивости и расширения очага заражения плероцеркоиды широкого лентеца эволюционно выработали способность сохранять инвазионность при поедании зараженных рыб хищниками, в число которых входят крупный окунь, щука, налим.

До зарегулирования реки и создания водохранилища в верховьях Енисея широкий лентец не встречался (Артамошин, Павленко, 1972; Плющева и др., 1989; Плющева, Герасимов, 1995), в низовьях он был зарегистрирован как очень редкий паразит рыб (Бауер, 1948). Гидрологические особенности реки, а именно высокие скорости течения на уровне горного потока, ограничивали развитие планктона необходимого звена в развитии паразита. Доминирующей группой речного зоопланктона являлись коловратки, копеподы (первый промежуточный хозяин широкого лентеца) были малочисленными (Грезе, 1957).

В 1984 г. (по прошествии 14 лет после наполнения водоема) зараженность окуня плероцеркоидами в отдельных заливах составляла 11,4-17,5 \% (Романенко и др., 1986; Плющева и др., 1989), к 2004 г. она возросла до 44,0 \%, (Вышегородцев и др., 2005), в 2008-
2010 гг. (после 40-летнего существования водоема) колебалась от 31,5 до 52,2 \% (Чугунова, Вышегородцев, 2009; Чугунова, 2018). Аналогичная ситуация по дифиллоботриозу наблюдалась при создании ряда других водохранилищ (Рыбинского, Горьковского, Куйбышевского и др.), где на 3-4-й год существования водоема отмечался рост инвазии рыб цестодами (Изюмова, 1956; Изюмова, 1977; Романов, 1960).

Увеличение зараженности окуня Красноярского водохранилища с момента зарегулирования водоема обусловлено, прежде всего, ухудшением пищевой обеспеченности рыб. Значительная сработка уровня водохранилища - до 19 м (Вышегородцев и др., 2005), уменьшение выноса биогенов из затопленных почв и разлагающейся растительности, замещение продуктивных грунтов наносами с малым содержанием органических веществ определяют невысокую биомассу и численность бентосных организмов. С другой стороны, последовавшее после зарегулирования водоема эвтрофирование повлекло за собой развитие зоопланктона. Окунь - эврифаг, у которого в условиях нехватки бентоса произошла смена пищевой специализации и он вынужденно перешел на питание зоопланктоном. Причем это касается как молоди, так и взрослых рыб (3+-5+ лет).

Крупный окунь преимущественно хищник, поедая молодь ерша и собственную молодь, заражается диботриоцефалюсом посредством реинвазии, что способствует циркуляции дифиллоботриоза (рис. 3). Высокая зараженность окуня $(E=68,5 \%, I=2,8$ экз.), купленного на стихийном рынке, очевидно, обусловлена тем, что исследованная выборка представлена крупными рыбами в возрасте 4+-8+ лет, 60 \% из них шести- и семилетки длиной от 20 см и массой более 300 г. Наличие живых и активных личинок 


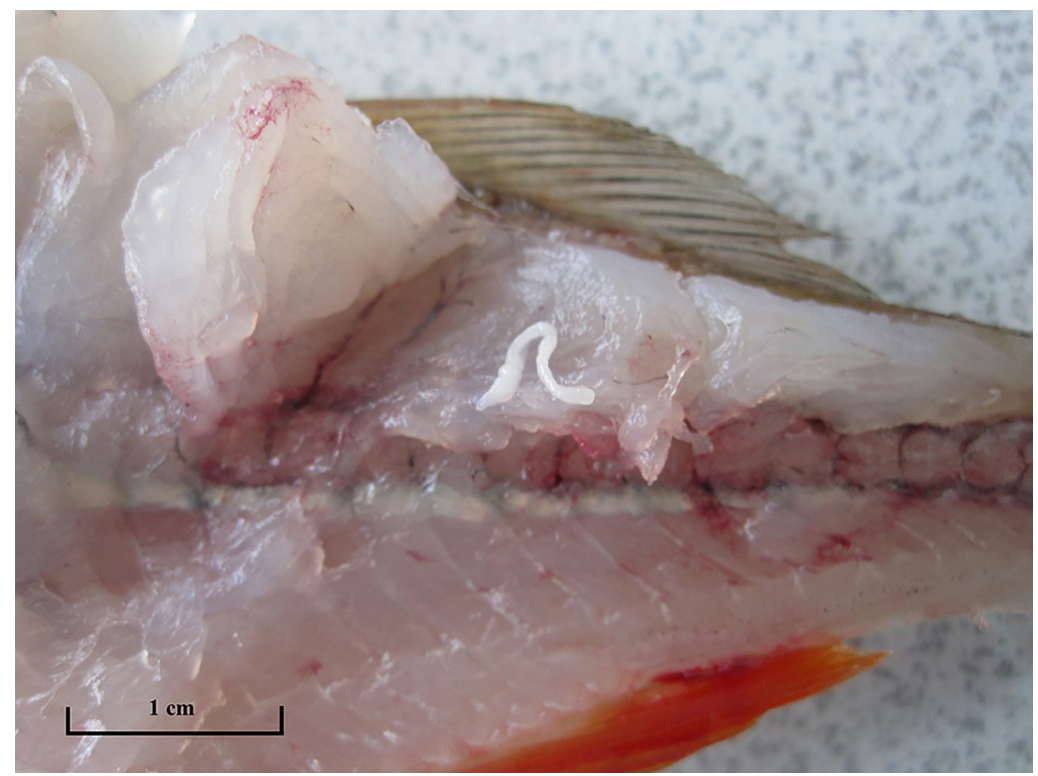

Рис. 3. Плероцеркоид лентеца широкого (D. latus) в мышцах окуня

Fig. 3. Plerocercoid of a tapeworm (D. latus) in muscle of a perch

в свежезамороженной рыбе позволяет нам предполагать, что возможное место вылова рыб - один из заливов Красноярского водохранилища. Незначительный объем продаваемой рыбы и отсутствие каких-либо ветеринарных сопроводительных документов на продукцию также косвенно свидетельствуют о том, что данная партия рыбы выловлена в местном водоеме, а не завезена из другого региона.

Минимальная зараженность окуня в зал. Бирюса Красноярского водохранилища обусловлена тем, что этот залив в силу своих гидрологических особенностей (глубоководный, каньонного типа) менее подвержен антропогенному воздействию. Еще И.В. Герасимовым (1987) было отмечено, что значительная (возможно, и ведущая) роль в загрязнении водоема яйцами лентеца широкого принадлежит рыболовецким точкам, санитарное состояние которых неудовлетворительное, а также рыболовецким судам, курсирующим по акватории и сбрасываю- щим фановые воды без очистки. Населенные пункты по берегам зал. Бирюса отсутствуют, основные рыбопромысловые точки расположены преимущественно в заливах средней и верхней частей водохранилища, любительское рыболовство развито в меньшей степени. Соответственно, попадание инвазионного начала здесь минимальное. Напротив, зал. Шумиха - ближайший крупный залив к городам Красноярску и Дивногорску, здесь расположены причалы и лодочные станции. На берегах зал. Шумиха имеется жилой частный сектор, дачные массивы, базы отдыха. В течение всего года отмечается значительное количество отдыхающих и рыбаков-любителей. Тенденция увеличения зараженности окуня Красноярского водохранилища по направлению к верховьям (зал. Сисим) обусловлена совокупностью гидрологических (в верховье самые крупные заливы с большой площадью мелководий), гидробиологических (благоприятные условия для развития зоопланктона, хорошая кормовая база для рыб) факторов, 
а также наличием крупных населенных пунктов с развитой инфраструктурой.

\section{Заключение}

В настоящее время в Красноярском водохранилище продолжает существовать очаг дифиллоботриоза. Подтверждение тому наличие плероцеркоидов в окуне, тенденция увеличения зараженности рыб личинками лентеца по направлению к верховьям, а также результаты ранее проведенных (Чугунова, 2018) исследований. Окунь в водохранилище - массовый вид, вылов которого (по данным промысловой статистики Енисейского территориального управления Росрыболовства) в 2018 г. составил 94 \% от общего вылова окуня в бассейне р. Енисей в Красноярском крае. Таким образом, основным вторым промежуточным хозяином лентеца широкого является именно окунь водохранилища в силу своей численности и характера питания.

Мелкий и крупный окунь, поступающий в продажу и не прошедший ветеринарно-санитарную экспертизу, потенциально опасен для здоровья населения.

\section{Список литературы / References}

Артамошин А.С., Павленко М.И. (1972) Обследование рыб и населения на дифиллоботриоз в районе верховья Енисея. Зоологические проблемы Сибири: материаль IV совещания зоологов Сибири. Новосибирск, Наука, с. 510-511 [Artamoshin A.S., Pavlenko M.I. (1972) Inspection of fish and human population for diphillobothriosis at the upper reaches of the Yenisei. Zoological problems of Siberia: Proceedings of IV Meeting of Zoologists of Siberia. Novosibirsk, Nauka, p. $510-511$ (in Russian)]

Бауер О.Н. (1948) Паразиты рыб реки Енисей. Известия ВНИОРХ. Т. 27. Л., ВНИОРХ, с. 97 156 [Bauer O.N. (1948) Parasites of fishes in the Yenisei River. Newsletter of All-Union Scientific Research Institute of Lake and River Fisheries. Vol. 27. Leningrad, VNIORH, p. 97 - 156 (in Russian)]

Бауер О.Н. (1958) Рыбы как источник гельминтозов человека. Основные проблемы паразитологии рыб. Л., Лениградский университет, с. 321 - 335 [Bauer O.N. (1958) Fish as a source of helminthiasis in humans. Major problems of fish parasitology. Leningrad, Leningrad State University, p. 321 - 335 (in Russian)]

Беклемишев В.Н. (1961) Термины и понятия, необходимые при количественном изучении паразитов и нидиколов. Зоологический журнал, 40(2): 149-158 [Beklemishev V.N. (1961) Terms and concepts necessary for the quantitative examination of parasites and nidicolous organisms. Journal of Zoology [Zoologicheskii zhurnal], 40(2): 149-158 (in Russian)]

Быховская-Павловская И.Е. (1985) Паразиты рыб. Руководство по изучению. Л., Наука, 122 c. [Bykhovskaya-Pavlovskaya I.E. (1985) Parasites of fish. Study Guide. Leningrad, Nauka, 122 p. (in Russian)]

Вышегородцев А.А., Космаков И.В., Ануфриева Т.Н., Кузнецова О.А. (2005) Красноярское водохранилищче. Новосибирск, Наука, 212 с. [Vyshegorodtsev A.A., Kosmakov I.V., Anufrieva T.N., Kuznetsova O.A. (2005) Krasnoyarsk Reservoir. Novosibirsk, Nauka, 212 p. (in Russian)]

Герасимов И.В. (1987) Выявление путей попадания яиц лентеца широкого в акваторию Красноярского водохранилища как основа построения профилактических мероприятий. Медиичинская паразитология и паразитарные болезни, 6: 72-77 [Gerasimov I.V. (1987) Revealing the ways via which tapeworm eggs enter the waters of the Krasnoyarsk Reservoir as the basis for developing 
preventive measures. Medical Parasitology and Parasitic Diseases [Meditsinskaya parazitologiya i parazitarnye bolezni], 6: $72-77$ (in Russian)]

Герман Ю.К., Вышегородцев А.А. (2004) Оценка эпидемиологической ситуации в водоемах бассейна Енисея. Вестник Красноярского государственного университета. Естественные науки, 7: 77-81 [German Yu.K., Vyshegorodtsev A.A. (2004) Assessment of an epidemiological situation in waterbodies of the Yenisei basin. Bulletin of the Krasnoyarsk State University. Natural Sciences [Vestnik Krasnoyarskogo gosudarstvennogo universiteta. Estestvennye nauki], 7: 77-81 (in Russian)]

Гинецинская Т.А. (1958) Жизненные циклы и биология личиночных стадий паразитических червей рыб. Основные проблемы паразитологии рыб. Л., Лениградский университет, c. 144- 183 [Ginetsinskaya T.A. (1958) Life cycles and biology of larval stages of parasitic fish worms. Major problems of fish parasitology. Leningrad, Leningrad State University, p. 144 - 183 (in Russian)]

Грезе В.Н. (1957) Кормовые ресурсы рыб реки Енисея и их использование. Известия ВНИOРХ. Т. 41. Л., ВНИОРХ, 236 c. [Greze V.N. (1957) Food resources of fish of the Yenisei River and use thereof. Newsletter of All-Union Scientific Research Institute of Lake and River Fisheries. Vol. 41. Leningrad, VNIORH, 236 p. (in Russian)]

Делямуре С.Л., Скрябин А.С., Сердюков А.М. (1985) Основы цестодологии. Т. 11. Дифиллоботрииды - ленточные гельминты человека, млекопитающих и птиц. Судариков В.Е. (ред.) M., Наука, 200 c. [Delyamure S.L., Scriabin A.C., Serdyukov A.M. (1985) Fundamentals of Cestodology. Vol. 11. Difillobotriida - tape helminthes of humans, mammals and birds. Sudarikov V.E. (ed.) Moscow, Nauka, 200 p. (in Russian)]

Изюмова Н.А. (1956) О зараженности хищных рыб Рыбинского водохранилища личинками широкого лентеца. Доклады Академии наук СССР, 110(4): 711-712 [Izyumova N.A. (1956) On infection rates of predatory fishes of the Rybinsk Reservoir with larvae of the broad tapeworm. Reports of Academy of Sciences of the USSR [Doklady Akademii nauk SSSR], 110(4): $711-712$ (in Russian)]

Изюмова Н.А. (1977) Паразитофауна водохранилищ и пути ее формирования. Л., Наука, 284 c. [Izyumova N.A. (1977) Parasitic fauna of reservoirs and ways of formation thereof. Leningrad, Nauka, 284 p. (in Russian)]

Клебановский В.А., Смирнов П.Л., Клебановская И.А., Обгольц А.А. (1977) Гельминтозы населения Восточного Таймыра (Хатангский район). Проблемы эпидемиологии и профилактики природоочаговых болезней в Заполярье. Корнилова Г.В. (ред.) Омск, Омский медицинский институт, с. 144-164 [Klebanovsky V.A., Smirnov P.L., Klebanovskaya I.A., Obgol'ts A.A. (1977) Helminthiases of the population of East Taimyr (Khatanga district). Problems of epidemiology and prophylaxis of natural focal diseases in the Polar region. Kornilova G.V. (ed.) Omsk, Omsk Medical Institute, p. 144-164 (in Russian)]

Козминская И.Ф. (1964) О распространении дифиллоботриоза в низовьях Енисея и роли озерных рыб в инвазии людей широким лентецом. Медицинская паразитология и паразитарные болезни, 33(1): 82-86 [Kozminskaya I.F. (1964) On the distribution of diphyllobotriasis in the lower reaches of the Yenisei and the role of lake fishes in broad tapeworm invasion of people. Medical Parasitology and Parasitic Diseases [Meditsinskaya parazitologiya i parazitarnye bolezni], 33(1): 82-86 (in Russian)]

Методические указания МУК 3.2.988-00 «Методы санитарно-паразитологической экспертизы рыбы, моллюсков, ракообразных, земноводных, пресмыкающихся и продуктов их пере-

$$
-307-
$$


работки» (утв. Главным государственным санитарным врачом РФ 25 октября 2000 г.). Гарант. Информационно-правовая система. URL: http://base.garant.ru/4178173/ [Guidelines MI 3.2.98800 "Methods of sanitary and parasitological examination of fish, mollusks, crustaceans, amphibians, reptiles and products of processing thereof" (app. by Chief Public Health Physician of the Russian Federation on October 25, 2000). Garant. Legal and information system. URL: http://base.garant. ru/4178173/ (in Russian)]

О состоянии санитарно-эпидемиологического благополучия населения в Красноярском крае в 2017 году: Государственный доклад (2018) Управление Федеральной службы по надзору в сфере защиты прав потребителей и благополучия человека по Красноярскому краю, 323 с. [On the state of sanitary and epidemiological welfare of the population in the Krasnoyarsk Territory in 2017: State report (2018) Office of the Federal service for supervision of consumer rights protection and human welfare in the Krasnoyarsk Territory, 323 p. (in Russian)]

Плющева Г.Л., Герасимов И.В. (1995) Становление очага дифиллоботриоза на СаяноШушенском водохранилище. Медиџинская паразитология и паразитарные болезни, 1: 20-22 [Plyushcheva G.L., Gerasimov I.V. (1995) The formation of the focus of difillobothriosis at the SayanoShushensky Reservoir. Medical Parasitology and Parasitic Diseases [Meditsinskaya parazitologiya i parazitarnye bolezni], 1: 20-22 (in Russian)]

Плющева Г.Л., Клебановский В.А., Герасимов И.В., Лосева Т.А., Дарченкова Н.Н., Смирнов П.Л., Обгольц А.А., Клебановская И.А., Старостина О.Ю., Бочарова Т.А., Маштаков Б.П., Куркатов С.В., Акулова Л.М., Володин Ю.Ф., Воробьева Н.П. (1989) Распространение и оценка возможностей формирования новых очагов описторхоза и дифиллоботриоза в бассейне Енисея. Медииинская паразитология и паразитарные болезни, 6: 54-60 [Plyushcheva G.L., Klebanovskiy V.A., Gerasimov I.V., Loseva T.A., Darchenkova N.N., Smirnov P.L., Obgol'c A.A., Klebanovskaya I.A., Starostina O.Yu., Bocharova T.A., Mashtakov B.P., Kurkatov S.V., Akulova L.M., Volodin Yu.F., Vorob'eva N.P. (1989) The distribution and evaluation of potential formation of new foci of opisthorchiasis and diphillobotriosis in the Yenisei basin. Medical Parasitology and Parasitic Diseases [Meditinskaya parazitologiya i parazitarnye bolezni], 6: 54-60 (in Russian)]

Пронин Н.М., Жалцанова Д.- С.Д., Пронина С.В., Некрасов А.В., Ринчино В.Л., Русинек О.Т., Санжиева С.Д., Белякова Ю.В., Кудряшов А.С. (1991) Динамика зараженности животных гельминтами. Улан-Удэ, БНЦ СО АН СССР, 202 с. [Pronin N.M., Zhaltsanova D.-S.D., Pronina S.V., Nekrasov A.V., Rinchino V.L., Rusinek O.T., Sanzhieva S.D., Belyakova Yu.V., Kudryashov A.S. (1991) The dynamics of helminthes infestation of animals. Ulan-Ude, Buryat Scientific Center of the Siberian Branch of Academy of Sciences of the USSR, 202 p. (in Russian)]

Романов И.В. (1960) Распространение дифиллоботриоза в районе Горьковского водохранилища. Медицинская паразитология и паразитарные болезни, 5: 611-614 [Romanov I.V. (1960) Distribution of diphyllobothriasis in the Gorky Reservoir area. Medical Parasitology and Parasitic Diseases [Meditsinskaya parazitologiya i parazitarnye bolezni], 5: 611-614 (in Russian)]

Романенко Н.А., Клебановский В.А., Плющева Г.Л., Артамошин А.С., Обгольц А.А., Герасимов И.В., Сулейманов Н.Т., Левицкая Н.А., Старостина О.Ю., Степанов Л.Г., Немиро Т.В., Володин Ю.Ф., Воробьева Н.П. (1986) Возникновение и современное состояние очага дифиллоботриоза на Красноярском водохранилище. Медицинская паразитология и паразитарные болезни, 1: 69-73 [Romanenko N.A., Klebanovskij V.A., Plyushcheva G.L., Artamoshin A.S., 
Obgol'c A.A., Gerasimov I.V., Sulejmanov N.T., Levickaya N.A., Starostina O.Yu., Stepanov L.G., Nemiro T.V., Volodin Yu.F., Vorob'eva N.P. (1986) Emergence and the current state of the focus of diphyllobotriosis at the Krasnoyarsk Reservoir. Medical Parasitology and Parasitic Diseases [Meditsinskaya parazitologiya i parazitarnye bolezni], 1: 69-73 (in Russian)]

Чебышев Н.В., Далин М.В., Гусев В.К., Гузикова Г.С., Карпенко Л.П., Демченко А.Н. (2004) Атлас по зоопаразитологии. М., ИНТЕРХИМ, 173 с. [Chebyshev N.V., Dalin M.V., Gusev V.K., Guzikova G.S., Karpenko L.P., Demchenko A.N. (2004) Atlas of zooparasitology. Moscow, INTERKHIM, 173 p. (in Russian)]

Чугунова Ю.К., Вышегородцев А.А. (2009) Паразитофауна рыб Красноярского водохранилища (видовой состав, эпизоотическая ситуация). Проблемы и перспективы использования водных биоресурсов Сибири в ХХІ веке: мат. Всерос. конф. Красноярск, 8-12 декабря 2008 г. Красноярск, ИПК СФУ, с. 366-370 [Chugunova Yu.K., Vyshegorodtsev A.A. (2009) Parasitic fauna of fishes of the Krasnoyarsk Reservoir (species composition, epizootic situation). Problems and prospects of the use of water bioresources of Siberia in the 21 $1^{\text {st }}$ century: Proceedings of the All-Russian Conference. Krasnoyarsk, December 8-12, 2008. Krasnoyarsk, Institute of Professional Development of Siberian Federal University, p. 366-370 (in Russian)]

Чугунова Ю.К. (2018) Развитие антропогенных очагов гельминтозов при трансформации водоемов на примере Красноярского водохранилища. Труды Карельского научного иентра Российской академии наук. Серия: Экологические исследования, 5: 58-64 [Chugunova Ju.K. (2018) Development of helminthiasis pestholes of anthropogenic origin during transformation of water bodies, example of Krasnoyarskoye storage reservoir. Transactions of Karelian Research Centre of Russian Academy of Science. Ecological Studies Series [Trudy Karel'skogo nauchnogo tsentra Rossiiskoi akademii nauk. Seriya: Ekologicheskie issledovaniya], 5: 58-64 (in Russian)]

Bazsalovicsová E., Koleničová A., Králová-Hromadová I., Minárik G., Šoltys K., Kuchta R., Štefka J. (2018) Development of microsatellite loci in zoonotic tapeworm Dibothriocephalus latus (Linnaeus, 1758), Lühe, 1899 (syn. Diphyllobothrium latum) using microsatellite library screening. Molecular \& Biochemical Parasitology, 225: 1-3

Rozsa L., Reiczigel J., Majoros G. (2000) Quantifying parasites in samples of hosts. Journal of Parasitology, 86(2): 228-232

Scholz T., Garcia H.H., Kuchta R., Wicht B. (2009) Update on the human broad tapeworm (genus Diphyllobothrium), including clinical relevance. Clinical Microbiology Reviews, 22(1): 146-160

Waeschenbach A., Brabec J., Scholz T., Littlewood D.T.J., Kuchta R. (2017) The catholic taste of broad tapeworms - multiple routes to human infection. International Journal for Parasitology, 47(13): $831-843$ 